\title{
Margaret McCartney: Mandatory flu vaccination won't fix the NHS
}

\author{
Margaret McCartney general practitioner
}

Glasgow

Bruce Keogh, national medical director for NHS England, recently called for a "serious debate on mandatory flu vaccination." And the chief medical officer for England, Sally Davies, has indicated her support for mandatory flu vaccination for NHS staff. ${ }^{23}$ This would be a mistake.

Hepatitis B vaccination, for example, is a highly evidence based programme, usually requiring only three doses for lifelong protection. Flu vaccinations must be repeated every year, meaning a need for long term cooperation. Also, the benefits to healthcare workers (and hence patients) from flu vaccination are not so clear. ${ }^{45}$ Flu vaccinations may not work terribly well, and forcing staff to have a yearly vaccine of uncertain effectiveness is an odd use of authority.

We all know that the good ship NHS is kept afloat through difficult times because healthcare staff give their time and energy beyond the letter of their contract. Morale is a precious thing, and it can be buoyed as well as scuppered. Staff may reasonably ask about the relative effect of overcrowded wards on the spread of infection, staff ratios, and patient safety. Perhaps we should consider mandatory flu vaccination for staff after we've sorted safe staffing ratios and bed numbers.

Other uncertainties are worth contemplating. Research has found a link between increased flu vaccination and decreased sickness absence. ${ }^{6}$ This may reflect better organised trusts being associated with less sick leave. Vaccinated staff who believe that they are protected against flu may not in fact be (the vaccine's effectiveness was $41 \%$ in adults under 65 in 2016-17 ${ }^{7}$ ), and they may attend work when mildly unwell, presuming that it's not the flu and potentially transmitting the virus.

The benefits of flu vaccination for staff are probably seen best in care homes. ${ }^{8}$ Cluster randomised controlled trials in the UK have found lower death rates and health service use where care home staff are vaccinated. ${ }^{9}$ This would be an obvious place to ensure that flu vaccines are routinely offered.

Locally, however, many staff working in private nursing homes have told me that they'd like to be vaccinated but haven't been offered it. Some healthcare workers have told me that they've been unable to book-or find-occupational health appointments, such are their shift patterns. Easy access should be mandatory first.

The mandatory vaccination argument feeds a line to the media that the stress on the NHS is caused by staff failings

The best places to work are those where we find mutual respect. The mandatory vaccination argument feeds a line to the media that the stress on the NHS is caused by staff failings: yet it's those staff who hold up the NHS despite everything it's subjected to.

We'd be in a different situation if healthcare workers were offered vaccination with a full admission of its uncertainty, as well as a clear commitment to tackling organisational stress systematically. This, at least, might feel like the kind of relationship we'd want with our patients.

\section{Competing interests: See www.bmj.com/about-bmj/freelance-} contributors/margaret-mccartney.

Provenance and peer review: Commissioned; not externally peer reviewed.

Follow Margaret on Twitter, @mgtmccartney

Twitter. @DrBruceKeogh. 5 Jan 2017.

2 Davies S; Department of Health and Social Care. Chief medical officer advises NHS staff to make sure they are vaccinated against flu. 11 Jan 2018. https:/www.gov.uk/government/ news/chief-medical-officer-advises-nhs-staff-to-make-sure-they-are-vaccinated-againstflu.

3 Donnelly L, Scott P. Flu levels soaring with one in five hospital cases suffering "Aussie flu." Telegraph 11 Jan 2017. www.telegraph.co.uk/news/2018/01/11/flu-levels-soaringone-five-hospital-cases-suffering-aussie/.

4 Kliner M, Keenan A, Sinclair D, Ghebrehewet S, Garner P. Influenza vaccination for healthcare workers in the UK: appraisal of systematic reviews and policy options. BMJ Open 2016:6:e12149. doi:10.1136/bmjopen-2016-012149.27625062

5 De Serres G, Skowronski DM, Ward BJ. Influenza vaccination of healthcare workers critical analysis of the evidence for patient benefit underpinning policies of enforcement. PLoS One 2017;12:e0163586. doi:10.1371/journal.pone.0163586. https://doi.org/10.1371/ journal.pone.0163586.28129360

6 Pereira M, Williams S, Restrick L, Cullinan P, Hopkinson NSLondon Respiratory Network. Healthcare worker influenza vaccination and sickness absence - an ecological study. Clin Med (Lond) 2017;17:484-9. doi:10.7861/clinmedicine.17-6-48429196347

7 Public Health England. Influenza vaccine effectiveness (VE) in adults and children in primary care in the United Kingdom (UK): provisional end-of- season results 2016-17. https://www.gov.uk/government/uploads/system/uploads/attachment_data/file/641162/ Influenza_vaccine_effectiveness_in_primary_care_1617_final.pdf. 
8 Thomas RE, Jefferson T, Lasserson TJ. Influenza vaccination for healthcare workers who care for people aged 60 or older living in long-term care institutions. Cochrane Database Syst Rev 2016;6:CD005187.27251461

9 Hayward AC, Harling R, Wetten S. Effectiveness of an influenza vaccine programme for care home staff to prevent death, morbidity, and health service use among residents: cluster randomised controlled trial. BMJ 2006;333:1241-7.

doi:10.1136/bmj.39010.581354.55.17142257

Published by the BMJ Publishing Group Limited. For permission to use (where not already granted under a licence) please go to http://group.bmj.com/group/rights-licensing/ permissions 